\title{
What Drives The Riders To Personalizing Activity Toward Their Motorbike?
}

\author{
Dandi Yunidar \\ Product Design \\ Telkom University Bandung, Indonesia \\ dandiyunidar@telkomuniversity.ac.id
}

\author{
Ahmad Zuhairi Abdul Majid \\ Product Design \\ University Sains MalaysiaPenang, Malaysia \\ majid.zuhairi@usm.my
}

\begin{abstract}
This study was driven by a phenomenon that took place in Bandung Indonesia related to significant amount of motorbikes operate in Bandung until 2017. This huge amount of motorbike also creates several unique styles of riders. This study was conducted to find out is there any relationship between the rider's style and their life value that creates uniqueness when it comes about personalized motorbike, which in turn will creates map about the relationship between rider's value of live and their personalized motorbike. To define such relationship, psychographic method was used to describe and divide the riders into several groups based on VAIL (Value, Attitude, Interest, Lifestyle) parameters. The result clearly shows that there are some relationships between rider's value of live and their personalizing activity toward their motorbike.
\end{abstract}

Keywords: Lifestyle products, personalizing activity, Motorbike, Psychographic, Life value

\section{INTRODUCTION}

According to data from Badan Pusat Statistik Jawa Barat, there are about 2.906.286 units of motorcycle operate in Bandung in 2017, on the other hand the city it selves populated by about 2.470 .802 residents. There are various social and environmental phenomena that occur due to huge numbers of motorbike population in Bandung, including the emergence of various motorbike communities, road congestion, higher rates of traffic accidents, increasing levels of air pollution, and others. From some of the above, the most interesting is the emergence of the phenomenon of motorbike personalization carried out by the owner. This personalizing activity may occur due to a motorbike as a mass industrial product that certainly has shape, colour and standard specifications, and produced in large quantities. Although the manufacturer offers several alternative variants, but basically motorbike products is a mass product that cannot possibly fulfil everyone's taste, so the owners make additions, or modify the appearance of their motorbike to match the style of the owner or to meet the owner's need.

What it means by the personalization phenomenon in this matter is the activities of the owners of the motorbike to make changes, either in the form of reduction or addition something on their motorcycle. The problem is there was no study conducted yet to find out the relationship between the rider's style and their value of live that creates uniqueness when it comes about personalized motorbike.

\section{LITERATURE REVIEW}

Norman mentioned in his book that it is impossible to make or build a mass-produced item that fits for everyone, but there are some possibility to make people get along well with the product, customize and modify the massproduced item/product are some of the possible ways mentioned by Norman [1].

Indeed not everyone wants to change the appearance of the mass-produced item/product they have, especially those who value the authenticity of the item/product, but often the situation forces or motivates someone to make some small or big changes to their belonging (item/product). When we need to describe what kind of person is making changes to the product, we can use the psychographic method to break it down.

Psychographic is a method to observe and learn about one's reaction toward surrounding condition based on one's value of live and lifestyle. As a form of social group analysis, psychographic can be used to plan and set a more effective communication. Psychographic could help us to be more understand to whom we communicate, what is our opponent respond and how do they react toward negative or positive things, which in return gives us possibility to detect about their psychological, emotional or even spiritual state changes. We can use this method to anticipate the respond of particular individual toward various things.

This method was created in 1960 by Arnold Mitchell, originally was used and developed as a tool in social statistic field by the time he worked as a mathematician in Princeton University, which then also developed and used for psychology field.

Psychographic profiling will categorize people into unique typologies based on their real values and lifestyle. In accordance with the changes happens, all typologies also change, and the way we communicate with them must also change. Basically psychographic method divides market into several segmented groups based on social class, lifestyle, and personality [6]. For example the same group member in demography may have a very different psychographic character. Suppose an 18 years old teenager from the middle class would tend to choose a mall or branded distribution store to shop for clothes, while a teenager of the same age but from the lower classes do not really care where he can buy clothes. Neal included categories like product class behaviour, product class attitude, product class preferences as some of important base elements for segmenting a market [7], which is goes along very well with psychographic elements. 


\section{METHODOLOGY}

This study will be conducted in two ways that will be carried out simultaneously. Questionnaire will be given to the respondents and at the same time the author also observes randomly the activities of the rider and the types of changes that the riders made to their motorbikes.

There were 60 respondents who were involved in the data extraction using the psychographic method in this study, which the respondents consisted of motorbike riders belonging to the productive age in the city of Bandung. 60 of these respondents were scattered in three locations, each of which represented the routine activities of the motorbike riders. The three locations are: traditional markets at Gede bage (20 respondents), offices at PHH Mustopa street (20 respondents), and campus at Telkom University (20 respondents).

Sixty of these respondents were faced with a questionnaire containing four positive statement groups where each group statement had its function in extracting data from respondents. The first group were meant to find out the respondents life value, the second group were meant to find out about their attitude, the third group were about respondents interest, and the fourth were about respondents lifestyle.

All positive statements in the questionnaire will be assessed by the parameter scale contained in figure. 1 . The result from this questionnaire will classify the respondents into several typologies.

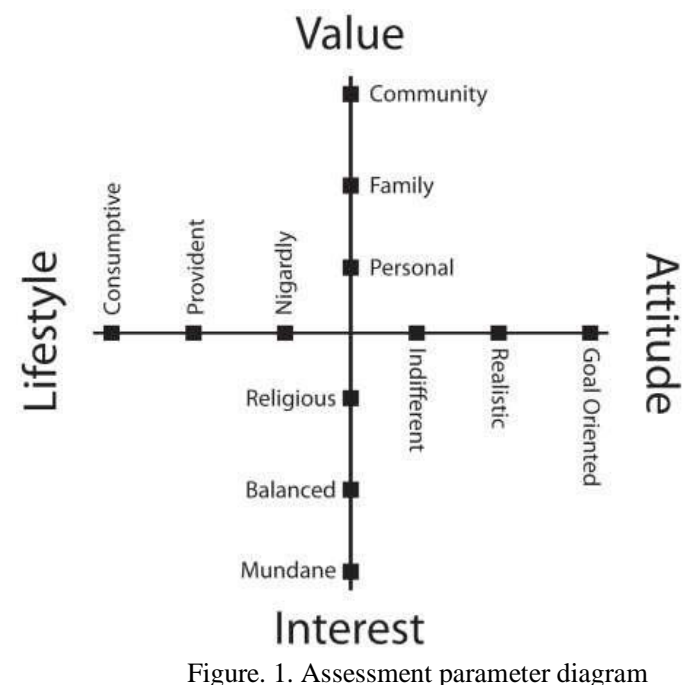

\section{RESULT}

The majority of the 20 respondents who participated in the Gede bage traditional market area as it shown in figure 2 were the type of riders who had a strong bond to the family, they were also realistic people in making decisions, they also felt that religious affairs were very important in their lives, and for sure they were the type of people who are very calculating in managing their finances.

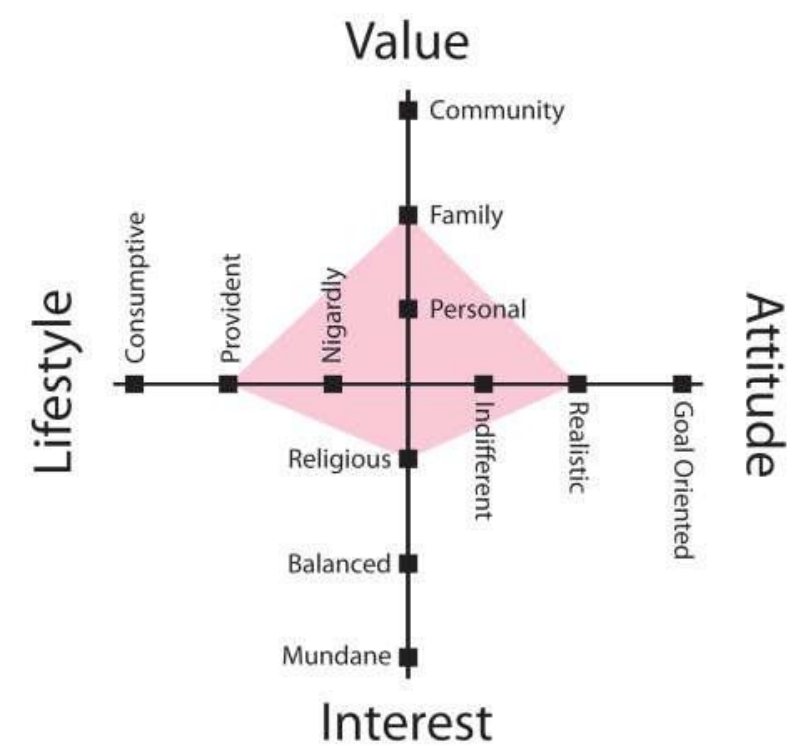

Figure. 2. Result from assessment at Gede Bage traditional market

The majority of the 20 respondents who participated in the PHH Mustopa office area as it shown in figure 3 were the type of riders who think that personal values are the main thing, they are also people who are very goal oriented in making decisions, they also feel that religious and worldly affairs is a very important thing to live in a balanced manner, and certainly they were the type of people who are very calculating in managing their finances.

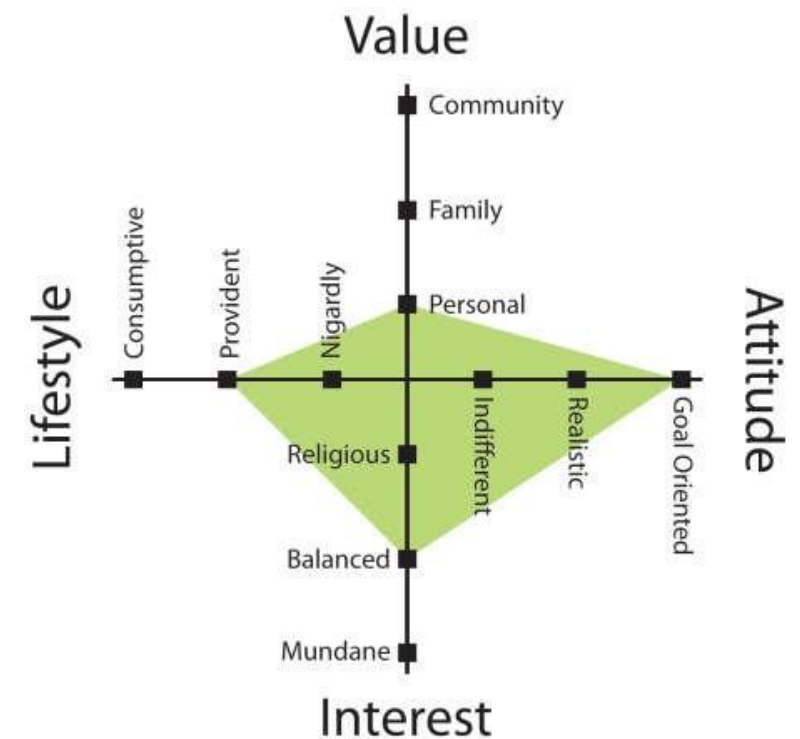

Figure. 3. Result from assessment at offices around PHH Mustopa street

The majority of the 20 respondents who participated in the Telkom University campus area as it shown in figure 4 were the type of riders who think that community values are very important for them, they were also people who are very goal oriented in making decisions, they also felt that worldly affairs is a very important thing to pay attention to and pursue, and they were the type of people who are very appreciative and have strong motivation to be able to follow the development of lifestyle products. 


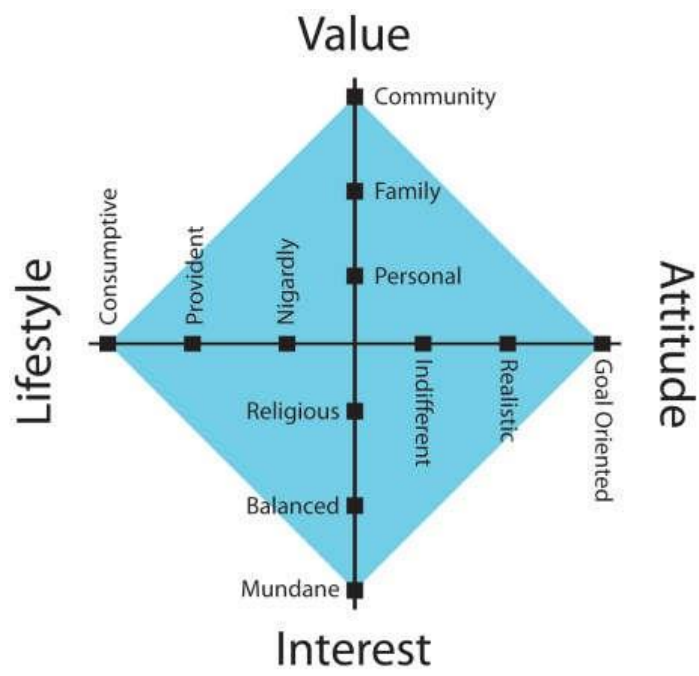

Fig. 4. Result from assessment at Telkom University campus

\section{DISCUSSION}

Base on what questionnaire and observation found in some areas above the respondents can be segmented as in table 1 below, and they can be summarized in three types of riders as passive type, reactive type, and active type.

Table I. Respondent's psychographic profiles base on questionnaire and observation.

\begin{tabular}{|c|c|c|c|}
\hline & $\begin{array}{c}\text { Seller at Gede } \\
\text { bage } \\
\text { tradistional } \\
\text { market }\end{array}$ & $\begin{array}{c}\text { Workers at } \\
\text { offices at } \\
\text { PHH } \\
\text { Mustopa St }\end{array}$ & $\begin{array}{c}\text { Students at } \\
\text { Telkom } \\
\text { University }\end{array}$ \\
\hline $\begin{array}{l}\text { Motorbike } \\
\text { function }\end{array}$ & $\begin{array}{l}\text { As a personal, } \\
\text { family, or } \\
\text { commercial } \\
\text { means of } \\
\text { transportation }\end{array}$ & $\begin{array}{l}\text { As a means of } \\
\text { personal or } \\
\text { family } \\
\text { transportation, } \\
\text { and as a } \\
\text { medium for } \\
\text { socializing }\end{array}$ & $\begin{array}{l}\text { As a medium } \\
\quad \text { for } \\
\text { socializing, } \\
\text { expressing, } \\
\text { and } \\
\text { as a means of } \\
\text { personal } \\
\text { transportation }\end{array}$ \\
\hline $\begin{array}{c}\text { The intensity } \\
\text { of changes on } \\
\text { motorbike }\end{array}$ & $\begin{array}{l}\text { Very minimal } \\
\text { or even if there } \\
\text { is a very } \\
\text { functional in } \\
\text { accordance } \\
\text { with the } \\
\text { demands of its } \\
\text { activities }\end{array}$ & $\begin{array}{c}\text { Wearing } \\
\text { accessories, } \\
\text { both of which } \\
\text { have practical } \\
\text { functions or } \\
\text { just for styles } \\
\text { that are not too } \\
\text { much in } \\
\text { intensity }\end{array}$ & $\begin{array}{l}\text { Use a lot of } \\
\text { accessories, } \\
\text { both that have } \\
\text { practical } \\
\text { function or just } \\
\text { for style, and } \\
\text { they are } \\
\text { mostly very } \\
\text { idealistic } \\
\text { in a good style } \\
\text { to show their } \\
\text { personal or } \\
\text { community } \\
\text { identity }\end{array}$ \\
\hline $\begin{array}{c}\text { Balance } \\
\text { between style } \\
\text { and function }\end{array}$ & $\begin{array}{l}\text { Very } \\
\text { functional }\end{array}$ & $\begin{array}{l}\text { Functional and } \\
\text { stylish }\end{array}$ & $\begin{array}{l}\text { Functional and } \\
\text { very stylish }\end{array}$ \\
\hline $\begin{array}{c}\text { Awareness for } \\
\text { driving } \\
\text { equipment } \\
\text { standards }\end{array}$ & $\begin{array}{c}\text { Less caring, } \\
\text { and sometimes } \\
\text { ignore driving } \\
\text { safety without } \\
\text { using standard } \\
\text { safety } \\
\text { equipment }\end{array}$ & $\begin{array}{l}\text { Have a good } \\
\text { awareness to } \\
\text { use safety } \\
\text { standard } \\
\text { equipment for } \\
\text { driving }\end{array}$ & $\begin{array}{l}\text { Have a good } \\
\text { awareness to } \\
\text { use safety } \\
\text { standard } \\
\text { equipment for } \\
\text { driving, but } \\
\text { sometimes the } \\
\text { safety }\end{array}$ \\
\hline & & & $\begin{array}{l}\text { standards are } \\
\text { ignored in } \\
\text { order to meet } \\
\text { the demands of } \\
\text { style }\end{array}$ \\
\hline
\end{tabular}

\begin{tabular}{|c|c|c|c|}
\hline $\begin{array}{c}\text { Description of } \\
\text { Value, } \\
\text { Attitude, } \\
\text { Interest and } \\
\text { lifestyle }\end{array}$ & $\begin{array}{l}\text { They are } \\
\text { people who } \\
\text { are able to } \\
\text { restrain } \\
\text { themselves in } \\
\text { desires, have } \\
\text { clear priorities } \\
\text { due to } \\
\text { compulsion or } \\
\text { indeed } \\
\text { intentionally, } \\
\text { most of them } \\
\text { are from the } \\
\text { middle class } \\
\text { with age above } \\
\text { 35, not brand } \\
\text { minded, and } \\
\text { they are } \\
\text { reluctant to try } \\
\text { something new } \\
\text { if it does not } \\
\text { have a } \\
\text { practical } \\
\text { function for } \\
\text { the routine. }\end{array}$ & $\begin{array}{l}\text { They } \\
\text { understand } \\
\text { priorities in } \\
\text { their lives, but } \\
\text { are also very } \\
\text { brand minded } \\
\text { in consuming } \\
\text { products and } \\
\text { like something } \\
\text { from the upper } \\
\text { social class } \\
\text { above them, } \\
\text { most of them } \\
\text { come from the } \\
\text { middle class } \\
\text { with age } 35 \text {, } \\
\text { they like to try } \\
\text { anything new }\end{array}$ & $\begin{array}{l}\text { They are very } \\
\text { brand minded } \\
\text { in consuming } \\
\text { goods, often } \\
\text { create trends } \\
\text { and dare to try } \\
\text { new things that } \\
\text { are not } \\
\text { common, } \\
\text { mostly from } \\
\text { middle and } \\
\text { upper class } \\
\text { with teenagers } \\
\text { up to> } 23 \text { years } \\
\text { old, usually } \\
\text { they are } \\
\text { minorities who } \\
\text { are member of } \\
\text { a community } \\
\text { with quite } \\
\text { strong } \\
\text { existence }\end{array}$ \\
\hline Summary & Passive type & Reactive type & Active type \\
\hline
\end{tabular}

There are five elements highlighted when searching for data as in table 1, these elements are about motorbike functions for each respondent in each area (obtained by question in the questionnaire), the intensity of changes on motorbikes (obtained by observation), balance between style and function (obtained by observation), awareness of standard driving safety equipment (obtained by observation and questions in the questionnaire), and the last element is a VAIL description obtained by questionnaire through a psychographic approach.

When the data from the five elements are displayed simultaneously in a table form (table.1) there appears a unique tendency created from each data search location area, where the tendency can be summerized as the respondent's topology.

\section{CONCLUSION}

Clearly there is a connection between the style of the riders in changing their motorbikes and the values of their lives. The relationship between the two is causal, where this causal relationship creates a unique tendency by each driver's topology in changing the appearance of the motorbike.

Each topology has its own tendency which is influenced by the factors of life values that are believed by respondents, where the "values of life" influence the "attitude" of the respondents, which then determines the "interest" of the respondent, which in turn will shape the respondent's "lifestyle" (Figure.5). 


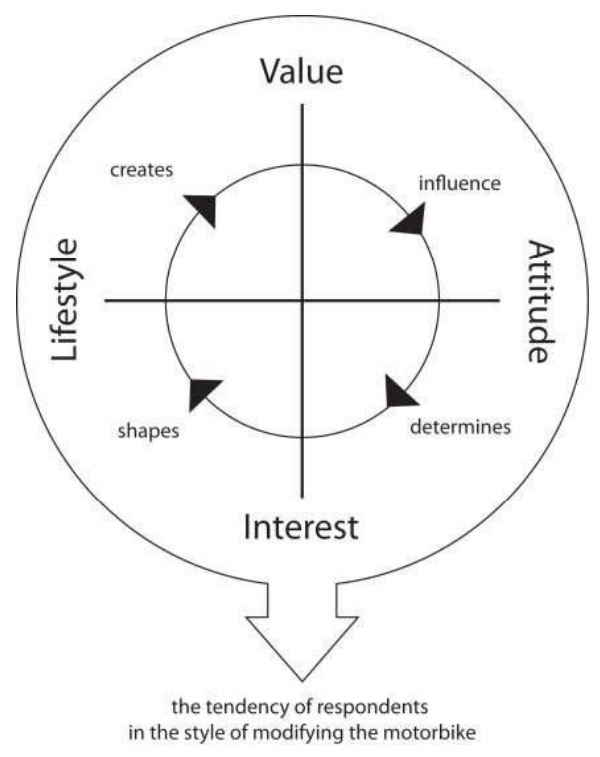

Figure. 5. Causal relationship between the rider's style in changing their motorbikes with their values of lives.

This continuous causal and circular relationship influence each other which ultimately creates a unique tendency for each type of driver in personalizing their motorbike (Fig.5).

That is what drives the riders do personalizing activity toward their motorbike

\section{REFERENCES}

[1] Norman, D. A., Emotional Design. Why We Love or Hate Everyday Things. New York. United States: Basic Book. 2004.

[2] Ibrahim, Idi Subandi. Lifestyle Ectasy. Kebudayaan Pop Dalam Masyarakat Komoditas Indonesia. Jalasutra. Yoyakarta. 1997.

[3] Goebert, B., \& Rosenthal, H. M. Beyond listening: Learning the secret language of focus groups. New York: J. Wiley. 2001. URL for chapter 1: Listening 101: The Value of Focus Groups. http//www.wileyeurope.com/cda/cover/0,,0471395625\%7C excerpt, 00 .pdf

[4] Harrion, S., \& Dourish, P. Re-place-ing space: the role of place in collaborative systems. ACM. Proceeding of the Conference on Computer Support of Collaborative Work (CSCW). New York: ACM. 1996.

[5] Solomon, Michael R. Consumer Behavior: Buying, Having, and Being. Upper Saddle River, NJ: Prentice Hall. 2002.

[6] Ciribeli. Joao Paulo, Miquelito, Samuel. Market Segmentation by Psychographic Criteria: an Essay on The Main Psychographic Theoritical Approaches and Its Relationship With Performance Criteria, Vision de Futuro Ano 12, Vulumen No19, No1, Enero - Junio 2015, pag 51 -64 .

[7] Neal, William D. Principles of Market Segmentations. AMA Core Marketing Knowledge: Segmentation. American Marketing Association. New York. 2005. 